\title{
Artikel
}

\section{De strafwetgever en kinderrechten: nog te veel een opgedrongen ideaal?}

\author{
Mr. dr. J. (Jolande) uit Beijerse*
}

\section{Inleiding}

We schrijven het jaar 2020. Het jeugdrecht, inmiddels 115 jaar oud, fungeert in Nederland reeds 25 jaar onder de vlag van het Verdrag inzake de Rechten van het Kind (IVRK). De opvatting van de regering ten tijde van de ratificatie van het verdrag in 1995 was, dat de Nederlandse wetgeving niet hoefde te worden aangepast, omdat die al voldeed aan de eisen van het verdrag. Gezien die terughoudende opstelling van de beleidsmakers was de aandacht in eerste instantie gevestigd op de doorwerking in de rechtspraak. ${ }^{1}$ Dat is ook gelukt. Het aantal uitspraken waarin naar het IVRK wordt verwezen neemt nog steeds toe, al stuiten principiële kwesties, zoals de redelijke termijn in jeugdstrafzaken en de opslag van het DNA-profiel van jeugdigen, vaak af op de opstelling van de Hoge Raad die nog niet erg geneigd is jeugdigen anders te behandelen. ${ }^{2}$

Deze kwesties tonen aan dat ook de strafwetgever met het IVRK aan de slag moet. In de afgelopen vijfentwintig jaar heeft deze niet stil gezeten. Al in het jaar van de ratificatie van het IVRK werd het jeugdstrafrecht ingrijpend herzien, en daarop zijn nog diverse herzieningen

Mr. dr. J. uit Beijerse is universitair hoofddocent straf- en strafprocesrecht aan de Erasmus Universiteit in Rotterdam

1. J.E. Doek, 'De ratificatie van het Verdrag voor de Rechten van het Kind. Enige beschouwingen over de mogelijke gevolgen voor de Nederlandse rechtspraktijk', NJCM-bulletin 1995, p. 10-21.

2. R. van de Water, 'De Hoge Raad heeft niets met kinderen (en het IVRK)', Ivoren Toga, 6 oktober 2015, http://ivorentoga.nl/archieven/ 3838. Maar zie het recente arrest van 7 april 2020, ECLI:NL:HR: 2020:626. gevolgd. Het gaat om herzieningen van het algemene straf- en strafprocesrecht die ook voor jeugdigen gelden, maar ook om herzieningen van het jeugdstrafrecht waaronder de Wet gedragsbeïnvloeding jeugdigen in 2008 en de Wet adolescentenstrafrecht in 2014. Op dit moment ligt er een conceptwetsvoorstel in het kader van Modernisering strafvordering, waarmee het hele jeugdstrafprocesrecht wordt herzien. De vraag is, of de strafwetgever bij die gelegenheden conform artikel 4 IVRK passende wettelijke maatregelen heeft genomen om de in het verdrag opgenomen minimumstandaard aan kinderrechten te verwezenlijken en zo ja, hoe?

\section{Jeugdstrafwetgeving voor en na het IVRK}

Dat de regering het idee had dat de wetgeving al aan de eisen van het verdrag voldeed en achterover kon leunen, is te danken aan het werk van Minister van Justitie Cort van der Linden. Die bracht ruim 90 jaar voor de ratificatie van het IVRK een apart jeugdstrafrecht tot stand met eigen procedures, opgebouwd rond uitgangspunten die nu in dat verdrag zijn terug te vinden. Jeugdstrafzaken werden waar mogelijk buitengerechtelijk afgedaan. Jeugdigen hadden voorts vanaf het eerste moment van aanhouding bijstand van een raadsman en van de ouders of voogd en die hadden niet op hun beurt vrij toegang tot de aangehouden jeugdige verdachte, alsmede tot alle verhoren. Vrijheidsbeneming moest tot het uiterste worden beperkt en ten uitvoer worden gelegd in gespecialiseerde jeugdinrichtingen, waarin het klimaat moest zijn gericht op opvoeding. Er werd standaard onderzoek gedaan naar de persoonlijke omstandigheden en de berechting vond plaats achter gesloten deuren in aanwe- 
zigheid van de jeugdige en ouders. Het is een genot om de memorie van toelichting te lezen en te zien hoe de minister werd gedreven door een kinderrechten-ideaal, niet als dogma, maar door per onderdeel inhoudelijk te onderbouwen wat het belang daarvan was. ${ }^{3}$

Paradoxaal genoeg stond de herziening van het jeugdstrafrecht in het jaar dat het IVRK werd geratificeerd, daar in alle opzichten diametraal tegenover en was deze volledig gespeend van enig kinderrechten-ideaal. De goedkeuringswet ter ratificatie van het IVRK lag tegelijk met de behandeling van deze herziening, vanaf 1992, in de Kamer en de inhoud van het verdrag was dus bekend. Het is wrang om te zien dat in hetzelfde jaar dat het jeugdstrafrecht onder de vlag van het IVRK kwam, de jeugdstrafwetgeving grotendeels was ontdaan van al haar specifieke jeugdkenmerken en zoveel mogelijk was aangepast aan het volwassenenstrafrecht. Enkele van de voorgestelde wijzigingen, de afschaffing van de verschijningsplicht voor jeugdigen en de openbare berechting van jeugdigen, zijn gedurende het wetgevingstraject nog wel grotendeels teruggedraaid. Dat gebeurde echter niet vanwege het op handen zijnde IVRK, maar als gevolg van de inspanningen van de rechterlijke macht, die waarschuwde dat de kinderrechter anders geen mogelijkheden meer zou hebben om pedagogisch te handelen. Bij deze herziening werd er tevens uitdrukkelijk voor gekozen om artikel $77 \mathrm{~b} \mathrm{Sr}$, de bepaling die het mogelijk maakt om 16- en 17-jarigen een volwassenensanctie op te leggen, te behouden en de criteria voor toepassing zelfs nog te verruimen. Dat betekende dat bij de ratificatie door Nederland een voorbehoud moest worden gemaakt op artikel 37 sub c IVRK. ${ }^{4}$

Dat we nu toch weer een redelijk kindvriendelijk jeugdstrafrecht hebben, is niet te danken aan het IVRK, maar - heel verrassend - aan het feit dat een effectieve aanpak van de jeugdcriminaliteit vanaf de jaren negentig een belangrijk onderwerp van beleid werd. In 1994 verscheen het rapport van de Commissie Jeugdcriminaliteit onder voorzitterschap van Van Montfrans, wat leidde tot een hernieuwde aandacht voor het specialisme jeugd bij de politie en het Openbaar Ministerie, een versterking van de strafrechtelijke taak van de Raad voor de Kinderbescherming en de landelijke invoering van de jeugdreclassering. Omdat de oorzaak van jeugdcriminaliteit werd gevonden in de gezinsproblematiek, kwam er een meer individu- en gezinsgerichte aanpak met als effectief erkende ambulante interventies ter beïnloeding van het gedrag en het bieden van structuur. In de memorie van toelichting bij de Wet gedragsbeinvloeding jeugdigen (2008), waarmee het toepassen van deze interventies werd gestimuleerd en vergemakkelijkt, constateerde de regering terloops dat het streven om te komen tot een individuele aanpak niet alleen de effectiviteit van sancties verhoogde, maar ook uit het IVRK

3. Wijziging in de bepalingen betreffende het straffen en de strafrechtspleging ten aanzien aan jeugdige personen, Kamerstukken II 1897/98, 213, nr. 3.

4. Art. 2 van de Rijkswet van 24 november 1994, Stb. 1994, 862. volgde. Het doel was het bevorderen van de herintegratie van de jeugdige en de aanvaarding door de jeugdige van een opbouwende rol in de samenleving, wat ook is opgenomen in artikel 40 lid 1 IVRK. ${ }^{5}$

\section{Een einde aan de mogelijkheid van toepassing van een volwassenen-} sanctie?

Het verwezenlijken van de in het verdrag opgenomen minimumstandaard aan kinderrechten lijkt niet de eerste prioriteit te zijn geweest van de wetgever. Ook het gemaakte voorbehoud in verband met artikel $77 \mathrm{~b} \mathrm{Sr}$ had die niet. De Nederlandse regering is daar wel bij elke vijfjaarlijkse rapportage over de naleving van het verdrag door het VN-Kinderrechtencomité op aangesproken, maar dat heeft er uitsluitend toe geleid dat in 2008 bij wet de mogelijkheid is uitgesloten om bij de toepassing van dat artikel een levenslange gevangenisstraf op te leggen. De vele suggesties die in de literatuur en de praktijk zijn gedaan, ${ }^{6}$ hebben de wetgever echter niet tot actie aangezet. Zelfs de minst vergaande, om de criteria weer cumulatief te laten gelden, zijn niet opgevolgd.

Het 25-jarig bestaan van het voorbehoud lijkt een goede gelegenheid om serieus de discussie met elkaar aan te gaan of we deze uitzonderingsbepaling nog nodig hebben. Deze bepaling is het resultaat van een amendement dat tegen de zin van Minister van Justitie Cort van der Linden in de Strafrechtelijke Kinderwet van 1905 was ingevoegd vanwege de weerstand die destijds nog bestond tegen de verhoging van de bovengrens naar 18 jaar. Alleen al gezien die voorgeschiedenis lijkt de tijd meer dan rijp om dit relikwie uit het verleden te schrappen. Het nieuwe argument voor het behoud van de bepaling, dat in 1995 en opnieuw in 2014 werd gebruikt, was het belang van flexibilisering van de bovengrens. Dat werd in 1995 gepresenteerd als alternatief voor een apart adolescentenstrafrecht en in 2014 als onderdeel van het adolescentenstrafrecht. Dat lijkt op het eerste oog een redelijk argument, maar het feit blijft dat die flexibiliteit richting 16- en 17-jarigen op gespannen voet staat met het IVRK en de flexibiliteit richting 18- tot 23-jarigen juist wordt toegejuicht door het VN-Kinderrechtencomité. Waarom zouden we er niet voor kiezen om uitsluitend een flexibele bovengrens richting jongvolwassenen te hebben, zoals in Duitsland?

5. Kamerstukken // 2005/06, 30332, 3, p. 1, 12

6. O.a.: E.M. Mijnarends, Richtlijnen voor een verdragsconforme jeugdstrafrechtspleging, 'gelijkwaardig, maar minderiarig', Deventer: Kluwer, 1999, M. Waals, 'Toepassing van volwassenensanctierecht bij jeugdigen. De beperkingen van het sanctierecht voor jeugdigen', FJR 2005, p. 207-211, A. Bakker, 'Straffen als jeugdige of als volwassene? Een checklist voor de rechtspraktijk', Proces 2006, nr. 5, p. 189-196 en J. uit Beijerse, 'De toepassing van volwassenensancties op 16- of 17-jarigen: pro's, contra's en alternatieven', DD 2009, afl. 10, p. 1067-1088. 
Een in de praktijk van de rechtspraak veelgebruikt argument, dat de maximale lengte van de PIJ-maatregel in sommige gevallen onvoldoende zou zijn, is inmiddels weggenomen nu het mogelijk is om de PIJ-maatregel in dat soort gevallen om te zetten naar de tbs-maatregel (art. 6:6:33 Sv). Wel een steekhoudend argument is, dat in gevallen waarin een PIJ-maatregel niet mogelijk is en het maximum van vierentwintig maanden jeugddetentie voor een zwaar strafbaar feit tot onbegrip zou leiden, het draagvlak voor het jeugdstrafrecht zou kunnen worden aangetast. Maar zouden we dit knelpunt niet binnen het jeugdstrafrecht zelf kunnen adresseren door bijvoorbeeld voor ernstige feiten als moord en doodslag een langere jeugddetentie mogelijk te maken?

\section{Een einde aan de mogelijkheid van openbare berechting?}

Een ander overblijfsel van de weinig kindvriendelijke herziening van 1995 is de in artikel 495b lid 2 Sv opgenomen mogelijkheid om de zaak in het openbaar te behandelen als het belang van de openbaarheid van de zitting zwaarder moet wegen dan het belang van de bescherming van de persoonlijke levenssfeer van de jeugdige verdachte. Deze bepaling staat op gespannen voet met artikel 40 lid 2 onder b onderdeel vii IVRK, dat het privéleven van het kind volledig moet worden geëerbiedigd tijdens alle stadia van het proces. Volgens de toelichting in General Comment Nr. 24 moeten uitzonderingen op de besloten berechting zeer beperkt zijn en duidelijk in de wet worden omschreven. ${ }^{7}$ In Nederland bestaat al sinds 1905 de mogelijkheid tot het verlenen van bijzondere toegang tot de zitting, waarmee het aan openbaarheid ten grondslag liggende doel van publieke controle op de rechtspraak wordt gediend zonder de privacy van de jeugdige te schenden. Sinds enkele jaren hebben ook slachtoffers standaard toegang. Door naast de bijzondere toegang ook nog de mogelijkheid van volledig openbare berechting op te nemen, lijkt de rechter echter op twee gedachten te zijn blijven hinken. ${ }^{8}$ Deze mogelijkheid van openbare behandeling verstoort het evenwicht dat door middel van de bijzondere toegang is gevonden tussen artikel 6 EVRM en artikel 40 IVRK.

Een volledig openbare behandeling doet daarbij afbreuk aan het beginsel van fair trial dat bij jeugdigen een andere betekenis heeft dan bij volwassenen. Een van de garanties daarvoor is dat de jeugdige in staat is om effectief te participeren in het proces en dat het proces moet plaatsvinden in een atmosfeer van begrip, waarbij de

7. General Comment Nr. 24 (2019) on children's rights in the child justice system, par. 67

8. H.J.J. Talsma, 'In alle openheid? De openbare behandeling van jeugdstrafzaken in het licht van het Kinderrechtenverdrag', FJR 2006, p. 15 , 18. jeugdige de beschuldigingen, mogelijke consequenties en straffen moet kunnen begrijpen, en in staat wordt gesteld zich vrijelijk te uiten. Waar nodig moeten de procedures en praktijken in de rechtszaal daarop worden aangepast. ${ }^{9}$ In de zaken waarin er sprake was van een openbare behandeling, onder andere de Facebookmoord, kon daar feitelijk nauwelijks sprake meer zijn van participatie, omdat de jonge verdachten volledig dicht sloegen en niets meer durfden te zeggen. ${ }^{10}$ In die zaken zijn ook tekeningen van de jonge verdachten gemaakt, die in kranten zijn geplaatst en nog steeds zijn te vinden op internet. Dit staat op gespannen voet met het voorschrift in General Comment Nr. 24, dat verdragsstaten moeten zorgen voor een levenslange privacybescherming ten aanzien van door jeugdigen gepleegde delicten voor alle soorten media, inclusief sociale media. $^{11}$

Gezien deze bezwaren had mogen verwacht dat het tweede lid van artikel $495 \mathrm{~b} \mathrm{~Sv}$ bij gelegenheid van de modernisering van het jeugdstrafprocesrecht zou worden geschrapt of dat er op zijn minst kritisch naar zou worden gekeken. In de Contourennota is immers toegezegd om deze modernisering conform de uit het IVRK voortvloeiende eisen vorm te geven. ${ }^{12}$ De mogelijkheid om de zaak in het openbaar te behandelen is echter zonder enige toelichting overgenomen in het voorgestelde artikel 6.1.1.3.3.3.

\section{Tot slot}

Geconcludeerd kan worden dat de zelfgenoegzaamheid van de regering bij de ratificatie van het IVRK achteraf bezien misplaatst was. Buiten de uitzonderingsbepaling voor 16- en 17-jarigen en de mogelijkheid de berechting openbaar te maken, zijn er nog vele onderdelen van het jeugdstrafrecht die meer in lijn zouden kunnen worden gebracht met het IVRK. Denk aan het wettelijk verankeren en omschrijven van de verschillende jeugdspecialismes (o.a. de kinderrechter, jeugdofficier van justitie, jeugdrechtadvocaat, jeugdpolitie), het schrappen van de aantekening in de justitiële documentatie na een buitengerechtelijke afdoening door de officier van justitie, het behoud van de transactie in plaats van de strafbeschikking, de verkorting van de termijn van het verblijf in de politiecel, de aanpassing van de termijnen van het voorarrest, het wettelijk verankeren van de Kalsbeek-normen voor een spoedige berechting en het aanpassen van de DNA-wetgeving. Ten aanzien van al die onderdelen zijn er in de literatuur suggesties ter verbetering gedaan.

9. General Comment Nr. 24 (2019) on children's rights in the child justice system, par. 46

10. Zie hierover uitgebreider: J. uit Beijerse \& C.L. van der Vis, 'Een voorzet voor de modernisering van het jeugdstrafprocesrecht in lijn met het IVRK en met oog voor de knelpunten in de praktijk', Tijdschrift Modernisering Strafvordering 2019, p. 73

11. General Comment Nr. 24 (2019) on children's rights in the child justice system, par. 70

12. Kamerstukken // 2015/16, 29279, 278 (Contourennota), p. 96 
De wijze waarop de wetgever uitvoering heeft gegeven aan artikel 4 IVRK, is ronduit teleurstellend te noemen. In de honderden pagina's memories van toelichting bij de verschillende herzieningen van het jeugdstrafrecht in de afgelopen vijfentwintig jaar wordt het IVRK slechts een enkele keer genoemd. Soms zonder enkele context, soms om te verdedigen dat een voorstel, zoals de nieuwe mogelijkheid van omzetting van de PIJ naar de tbs, wel aan het IVRK voldoet, soms omdat het moet of zo uitkomt. Waar er wordt verwezen naar bepalingen uit het IVRK, zijn die in de meeste gevallen vrij willekeurig te berde gebracht zonder nadere beschouwingen, uitwerking en toepassing. Wat ontbreekt, is dat de wetgever zich in algemene zin laat leiden door een kinderrechtenideaal. Wellicht komt dat omdat het ideaal is opgedrongen en de wetgever dat niet heeft verinnerlijkt, zoals destijds Cort van der Linden dat wel had.

Het is ook nogal hectisch aan het wetgevingsfront vanwege de toenemende vragen vanuit de samenleving waarin kinderrechten (en mensenrechten), zacht gezegd, niet de boventoon voeren. Toch hadden de vele herzieningen van het jeugdstrafrecht een gelegenheid kunnen bieden om te bezien hoe de noden van de praktijk zo kunnen worden geadresseerd dat ze tevens voldoen aan de kinderrechtenstandaard van het IVRK. Dat zo'n verbinding goed mogelijk is, laat de Wet gedragsbeinvloeding jeugdigen zien waar de wens om effectiever te sanctioneren zorgde voor een meer kindvriendelijk jeugdstrafrecht. Nu kwam die verbinding min of meer bij toeval tot stand, maar daar zou ook meer bewust op kunnen worden ingezet. Strafwetgever pur sang, hoogleraar strafrecht en Minister van Justitie Modderman, zei daarover: "Idealisme is niet de schande maar de kracht van den wetgever, van den staatsman, mits het gepaard ga met de studie èn van het verleden, èn van de actualiteit, en zijne praktische uiting zich houde binnen de grenzen der mogelijkheid." 13

Geachte wetgever, is het niet de hoogste tijd om niet langer te volstaan met krampachtige en vaak loze verwijzingen naar het IVRK, maar het kinderrechten-ideaal te hanteren als leidend principe bij het aanpakken van praktische vraagstukken? Daar zouden de jongeren, de jeugdstrafrechtspraktijk, maar ook de samenleving bij gebaat zijn.

\section{Ciske de Rat}

Het verhaal wordt verteld door de schoolmeester bij wie het 'Pro Juventute-klantje' Franciscus Vrijmoeth in de klas komt, een jongen die volgens zijn moeder een straf van Onzelieveheer is voor wie de politie maandelijks aan de deur komt. Als Ciske door zijn moeder gedwongen wordt in een café te werken op het moment dat het hem juist zo goed gaat op school, gaat het mis. In een vlaag van woede scheurt moeder voor zijn ogen het mooie boek kapot dat Ciske van zijn vriendje Dorus had mogen lenen. Dan knapt er iets in Ciske. Hij pakt het vleesmes dat voor hem op tafel ligt en gooit het naar zijn moeder, die dodelijk wordt getroffen in de halsslagader. De schoolmeester, die inmiddels de gezinsvoogd van Ciske is geworden, stapt naar de kinderrechter om voor Ciske te pleiten. Het was immers een ongeluk.

\section{De kinderrechter mr. Van Loon:}

'Die daad van de Rat vraagt vergelding! Het is nonsens om dat te ontkennen, 't zou tegen de menselijke natuur ingaan, als hier niet gestraft merd. Als we alleen redeneren, ja dan is de Rat net zo onschuldig als een meek of een jaar geleden. Maar m'n gevoel, m'n instinct - 't kan me niet schelen hoe u het noemt - legt mij de plicht van de straffende gerechtigheid op. Door zijn hand heeft iemand het leven verloren, z'n eigen moeder ligt dood. De dader - zelfs al is het nu maar een kind, heeft recht op straf, recht op gelegenheid om boete te doen, recht om later bevrijd van zijn schuld in de maatschappij terug te komen! Maar mat is het "équivalent"? Wat is de schuldgraad, de maatstaf? De rechtsfilosoof, die hier antmoord op geeft, een bevredigend antwoord althans, moet nog geboren morden. "Ihr laszt den Arme schuldig merden"..., heeft Goethe gezegd. Maar ik zit voor de moeilijkheid om recht te plegen. ... "Ik kan u heus de verzekering geven, dat ik rechtvaardig én menselijk zal trachten te zijn. Maak u geen zorg. $U$ peet, dat ik die jongen altijd wel heb mogen lijden. Wat ik straks zei, mas eigenlijk debatteren met mezelf. Het is zo verdraaid moeilijk meneer, dit combinatie van recht en menselijkheid."”

Velen bemoeien zich vervolgens met de zaak:

'Orthodoxe rechtsfilosofen achten "opzettelijke leedaanbrenging" geboden. Hier moet de overheid straffen en raak ook! Hun idealistische tegenpartijders bepleiten een doelmatige, opvoedkundige correctie en een middengroep betoogt, dat straf melismaar geboden is, maar dat het belang van de delinquent uiteindelijke een rechter dient te leiden. ... Ook de "politiek" heeft zich van het geval meester gemaakt. Conservatieve belangstellenden wijzen op de toenemende vermildering als gevolg van de ontkerstening der massa. Zij eisen een duidelijke voorbeeldstelling, een zmare straf, liefst van een meervoudige rechtbank en niet van een Kinderrechter, die zij min of meer beschoumen als een door meekheid mislukt grote-mensenrechter en een creatie van sentimentele moderne psychologen. Van geen toevallige inzichten van één rechter mag het vonnis afhangen. Een "koel vonnis" van drie verantwoordelijke magistraten is nodig. ${ }^{\text {14 }}$ 